\title{
Comparative Evaluation of the Proximate Composition, Anti-Nutrients and Functional Properties of Some Underutilized Pulses
}

\author{
Ngozi Okechukwu-Ezike $^{1^{*}}$ Jane Munonye ${ }^{2}$ Aurthur Esiegwu ${ }^{1}$ \\ 1.Imo State University Owerri, PMB 2000 Owerri, Imo State, Nigeria \\ 2.AE- Federal University Ndufu-Alike Ikwo PMB 1010 Abakaliki,, Ebonyi State,Nigeria
}

\begin{abstract}
Comparative evaluation of nutritional, functional and anti-nutritional composition of black-eyed beans, blackturtle beans (akidi oji) and brown turtle beans (akidi uhie). The moisture content of the samples ranged from $7.86 \%$ for black beans sample to $8.66 \%$ for black-eyed beans sample. Crude protein content of the samples ranged from $19.54 \%$ for black-eyed beans to $22.62 \%$ for black beans. The protein content of the beans samples were significantly different $(\mathrm{p} \leq 0.05)$. The black beans sample had the highest protein content. Fat content of the beans samples ranged from $9.71 \%$ for black-eyed beans to $12.62 \%$ for black beans, while brown beans flour was $10.26 \%$.The fat content of the samples were significantly different $(\mathrm{p} \leq 0.05)$. The swelling index of the samples was significantly different at $(\mathrm{P}>0.05)$. Saponin content of beans flour samples were $0.67 \mathrm{mg} / 100 \mathrm{~g}$ for black-eyed beans, $1.62 \mathrm{mg} / 100 \mathrm{~g}$ for black beans and $1.47 \mathrm{mg} / 100 \mathrm{~g}$, for brown beans. The oven drying employed during processing led to the reduction of trypsin inhibitors. The alkaloid content of the beans flour samples were $0.27 \mathrm{mg} / 100 \mathrm{~g}$ for black-eyed beans, $0.34 \mathrm{mg} / 100 \mathrm{~g}$ for black beans and $0.22 \mathrm{mg} / 100 \mathrm{~g}$ for brown beans. The tannin content of the samples evaluated of the beans flour samples were $1.24 \mathrm{mg} / 100 \mathrm{~g}$ for black-eyed beans, $1.65 \mathrm{mg} / 100 \mathrm{~g}$ for black beans $1.47 \mathrm{mg} / 100 \mathrm{~g}$ for brown bean. The black beans sample had the highest value of proximate composition among the beans samples measured in terms of; protein, fat, ash and crude fiber contents. The research recommends increase in propagation and consumption of the black eyed beans.
\end{abstract}

Keywords: Black eyed beans, Black and Brown turtle beans, anti-nutrient

DOI: $10.7176 /$ FSQM/95-08

Publication date:March $31^{\text {st }} 2020$

\section{0: INTRODUCTION}

Legumes refer to the seeds of leguminosae including beans, peas and pulses which are plant sources of protein for both the high and low income earners. Cowpea, Vigna unguiculata (Black-eyed beans) is a legume of the family Fabaceae which grows annually in a warm climate with adequate rainfall (Duke, 2006). Black-eyed beans are loaded with various types of nutrients. They are rich in fiber, protein, iron, potassium, low in fat and calories, containing various amino acids such as tryptophan, histidine, methionine and lysine, (Eka, 2016). Black-eyed beans possess the calcium, manganese and phosphorus which are vital minerals to maintain the strength and structure of bones. Manganese assists in the formation of bones by regulating the enzymes and hormones which are involved in the process of bone metabolism. Black-eyed beans assist in the mineral density of bones that prevents bone break, fracture and osteoporosis, ensuring healthy bones. Also it is a must to balance the calcium and phosphorus levels in the body through consumption of black-eyed beans (Oyewole, 2006).

Black turtle beans and Brown turtle beans (Phaseolus vulgaris) are commonly known as (Akidi oji) and (Akidi uhe) among the Igbo speaking tribe (South East) of Nigeria (Odu, 2010). They serve as food for large number of people of tropical origin and constitute a very important source of dietary protein in West African Countries including Nigeria. The seeds can be processed into various products such as flour, protein concentrates, isolates, starch and extruded products. Brown turtle beans are popularly produced and consumed bean across the globe and a staple in several traditional dishes from Africa and Latin America. Brown turtle bean is packed with dietary fiber, starch, antioxidants and phenolic acids. Brown turtle beans are an awesome source of iron, manganese, folate, phosphorus, potassium and magnesium. They have been shown to help the management of diabetes, prevent the body from absorbing excess calories in order to help in weight loss, reduce recurrence of colon cancer and prevent cardiovascular disease.

Black turtle beans and Brown turtle beans are highly nutritious but underutilized in Nigeria (Odo, 2010). They contain some level of anti-nutrient which does not contribute to nutrition in any way instead they are toxicants that may cause low protein. Beans have long been recognized as a valuable source of plant protein, vitamins (thiamine and niacin), minerals ( $\mathrm{P}, \mathrm{K}, \mathrm{Ca}, \mathrm{Mg}$ ) and dietary fibre. There is considerable evidence in the literature that foods high in water-soluble dietary fibre (such as oats or bean products) and purified forms of water-soluble dietary fibre can reduce blood cholesterol (Johnston et al., 2015). Several studies have shown that bean products can lower serum cholesterol levels. Daily consumption of $100-135 \mathrm{~g}$ of dry beans reduced serum cholesterol levels by $20 \%$ thereby reducing the risk of coronary heart disease by $40 \%$ (Johnston et al., 2015). 
Despite the efforts to combat hunger and malnutrition in Nigeria, they are still widespread in both rural and urban communities. The low income groups suffer most because they lack resources to procure, prepare and utilize adequate diets. Under exploitation and neglect of our indigenous food crops due to lack of nutritional information and cumbersome processing time are some of the problems facing the utilization of black-eyed beans, black turtle beans and brown turtle beans. Raw brown turtle beans contain a toxin called phyto-haemaglutinin that can cause liver damage and should be soaked and the remaining liquid discarded. Brown turtle beans must be cooked before eating them. For this reason, it is always best to soak brown turtle beans and discard the soaked liquid before cooking them. Cooking dried brown turtle beans in a slow cooker is discouraged, since the toxin remains in the beans and water as well (Williams, 2007).

The aim of the study is to compare the nutrients, functional and anti-nutritional compositions of black eyed beans, black turtle beans(akidi oji) and brown turtle beans(akidi uhe) flours. This work involved the evaluation of proximate composition such as moisture, protein, fat, ash, crude fiber and carbohydrate, Functional properties such as water absorption capacity, oil absorption capability, bulk density and swelling index. Anti-nutrients to be determined are Saponin, trypsin inhibitor, Haemaglutin, alkaloids, phytate, and tannin.

The work was to create awareness on the nutrient composition of black turtle beans and brown turtle beans flours as well as reveal their functional and anti-nutritional properties.

\section{0: MATERIALS AND METHOD}

Black eyed beans, black turtle beans (Akidi ojii) and brown turtle beans (Akidi uhie) were purchased from a local Relief-Market Owerri. Other equipment to be used for processing was sourced from the Department of Food Science and Technology, Imo State University Owerri. One kilogram $(1 \mathrm{~kg})$ each of wholesome black-eyed beans, black turtle beans, ( Fig. 1, and Brown turtle Beans seeds (Fig. 2)were manually sorted to remove dirt, deshelled, oven dried at $70^{\circ} \mathrm{C}$, cooled, milled using attrition mill (Model, 289) and sieved to obtain the beans flours. Each flour sample was kept in an airtight container, until further use

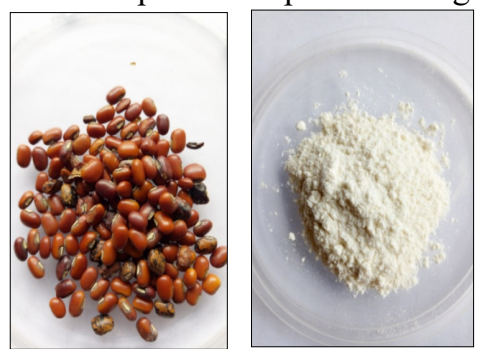

Figure 1: Black beans seed and Flour

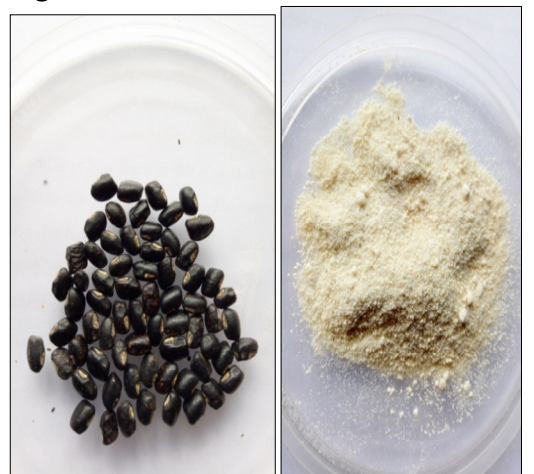

Figure 2: Black beans seed and Flour

\section{The Proximate Analyses of the Samples}

The standard methods of AOAC (2006) were used to determine the proximate compositions of the samples. The following parameters were determined: moisture content, protein, fat, fibre, ash and carbohydrate.

Functional properties determined were:

Water Absorption Capacity; the procedure described by Abbey and Ibeh (1998) was used to determine the water absorption capacity. One gram of the flour sample was weighed into centrifuge tube and $10 \mathrm{ml}$ of distilled water was added. The tube containing sample and distilled water was allowed to stand at room temperature for 30minutes after turning with stirrer and centrifuged at 5000rpm for 10 minutes. The volume of the supernatant was measured using $10 \mathrm{ml}$ graduated cylinder. The density value $1000 \mathrm{~kg} / \mathrm{m} 3$ was assumed and mean water absorption capacity obtained.

Oil Absorption Capacity: The oil absorption capacity was determined by the method of Abbey and Ibeh (1998). One gram of the sample was weighed into centrifuge tube and $10 \mathrm{ml}$ of power oil was added. The mixture was 
stirred and allowed to stand at room temperature for 30minutes. The sample in the tube was centrifuged at 5000rpm for 10minutes. The volume of free oil (supernatant) was read directly from the graduated centrifuge tube. Oil absorption capacity was expressed as grams of oil absorbed per gram of sample.

Bulk Density: The bulk density was determined according to the method described by (Gami et al., 1992). Ten calibrated measuring cylinder was weighed and sample was filled to the $10 \mathrm{ml}$ mark. The measuring cylinder containing sample was tapped on the laboratory bench until no further change in volume. The content was weighed and from difference in weight, the bulk density was calculated as shown in equation 1.

Bulk density $(\mathrm{g} / \mathrm{ml}) \quad=\quad$ weight of sample $(\mathrm{g})$

Volume of sample $(\mathrm{ml})$

Swelling Index: One gram of sample was transferred into a clean, dried graduated cylinder. Distilled water was added to the sample in the graduated cylinder to make up to $10 \mathrm{mls}$. The cylinder was swirled and allowed to stand for 60 minutes, while the change in volume was recorded every 15 minutes. The swelling power of sample was calculated using $\mathrm{H}_{2}$ as final height while $\mathrm{H}_{1}$ as initial height of the sample

Anti-nutrients

Saponin, trypsin inhibitor, Haemaglutin, Phytate, and Tannins were determined according to the standard method described by AOAC (2006). Five grams of the sample was weighed out into a conical flask and $100 \mathrm{~cm}^{3}$ of $20 \%$ aqueous ethanol was added. The sample was heated over a heated hot water bath for 4 hours with continuous stirring at about $55^{\circ} \mathrm{c}$. The mixture was filtered and residue re-extracted with another $200 \mathrm{ml}$ and $20 \%$ ethanol. The concentrate was transferred into a $250 \mathrm{ml}$ separating funnel and $20 \mathrm{ml}$ of diethyl ether and was vigorously shaked. The aqueous layer was discarded. The purification process was repeated. $60 \mathrm{mls}$ of n-butanol was added. The combined n-butanol extracts was washed twice with $10 \mathrm{ml}$ of $5 \%$ aqueous sodium chloride. The remaining solution was evaporated and oven dried to a constant weight.

Alkaloid determination was according to Harborne (2000). $5 \mathrm{~g}$ of the sample was mixed with Kmn04 solution to the point when a faint pink colour appeared that persisted for at least 30 seconds.

\section{Statistical Analysis}

Data obtained from the determinations was subjected to statistical analysis of variance (ANOVA) with the mean value separated by Duncan's multiple range tests at 5\% level of significance using SPSS version 2

\section{0: RESULTS AND DISCUSSIONS}

The moisture content of the samples ranged from $7.86 \%$ for black beans sample to $8.66 \%$ for black-eyed beans sample, falling within the acceptable limit of flour food samples thus ensuring for longer shelf life. Also the low moisture contents will inhibit the development of contaminating micro-organisms whose growth and activities are favored by the presence of high moisture (Table 1).

The Crude protein content of the samples ranged from $19.54 \%$ for black-eyed beans to $22.62 \%$ for black turtle beans. The protein contents of the beans samples were significantly different $(\mathrm{p} \leq 0.05)$. The black turtle beans sample had the highest protein content which could be attributed to the amino acid composition of the sample. The brown turtle beans also had a high protein content of $20.92 \%$ (Table 1), an indication that consumption of these beans will help to supply adequate amount of amino acids to the body, which in turn will help in replenishing loss body tissues.

The Fat content of the beans samples ranged from $9.71 \%$ for black-eyed beans to $12.62 \%$ for black beans, while brown beans flour was $10.26 \%$. The fat content of the samples were significantly different $(p \leq 0.05)$. Fat content of food samples aids in the improvement of mouth feel and flavor due to improved textural attributes of the food samples, thereby increasing consumers' acceptance and demand.

The Crude fibre content of the flour samples were $6.47 \%$ for black-eyed beans, $8.88 \%$ for black beans and $6.90 \%$ for brown beans. Fibre helps in the removal of waste products from the body, thereby preventing constipation and many health disorders. It will also help to prevent diseases such as diabetes mellitus, cardiovascular disease, obesity and colon cancer. The Ash contents of the samples were $0.87 \%$ for black-eyed beans, $2.44 \%$ for black beans and $1.96 \%$ for brown beans. Ash content is an indication of the level of minerals present in a particular food sample. Also black turtle beans had the higher ash value compared to black-eyed beans and brown beans samples. Carbohydrate content of a sample aids in determination of energy value of the food. Carbohydrate content of the samples produced were $54.74 \%$ for black-eyed beans, $45.57 \%$ for black beans and $52.43 \%$ for brown beans. The low carbohydrate content of the beans could be attributed to low level of amylose and amylopectin in the samples, since they are not pure carbohydrate foods. 
Table 1: Proximate composition of Black-eyed beans, Black beans and Brown beans flours.

\begin{tabular}{|c|c|c|c|c|c|c|c|}
\hline Parameter/Sample & $\begin{array}{l}\text { Moisture } \\
(\%)\end{array}$ & $\begin{array}{l}\text { Protein } \\
(\%)\end{array}$ & $\begin{array}{l}\text { Fat } \\
(\%)\end{array}$ & $\begin{array}{c}\text { Crude } \\
\text { fibre } \\
(\%)\end{array}$ & & $\begin{array}{l}\text { Ash } \\
(\%)\end{array}$ & $\begin{array}{c}\text { Carbohydrate } \\
(\%)\end{array}$ \\
\hline Black-eyed beans & $8.66^{a} \pm 0.02$ & $\begin{array}{ll}19.54^{\mathrm{c}} & \pm \\
0.03 & \end{array}$ & $\begin{array}{l}9.71^{\mathrm{a}} \pm \\
0.10^{-}\end{array}$ & $\begin{array}{l}6.48^{c} \\
0.02\end{array}$ & \pm & $\begin{array}{l}0.87^{c} \\
0.01\end{array}$ & $54.75^{a} \pm 0.11$ \\
\hline Black beans & $7.86^{\mathrm{c}} \pm 0.03$ & $\begin{array}{l}22.62^{\mathrm{a}} \pm \\
0.01\end{array}$ & $\begin{array}{l}12.62^{\mathrm{a}} \pm \\
0.02\end{array}$ & $\begin{array}{l}8.88^{\mathrm{a}} \\
0.05\end{array}$ & \pm & $\begin{array}{l}2.44^{\mathrm{a}} \pm \\
0.01\end{array}$ & $45.57^{c} \pm 0.08$ \\
\hline Brown beans & $8.55^{b} \pm 0.03$ & $\begin{array}{l}20.92^{\mathrm{b}} \pm \\
0.08\end{array}$ & $\begin{array}{l}10.26^{\mathrm{b}} \pm \\
0.02\end{array}$ & $\begin{array}{l}6.90^{\mathrm{b}} \\
0.02\end{array}$ & \pm & $\begin{array}{l}1.96^{\mathrm{b}} \pm \\
0.02^{-}\end{array}$ & $52.43^{\mathrm{b}} \pm 0.06$ \\
\hline LSD & 0.0196 & 0.0434 & 0.0288 & 0.0131 & & 0.131 & 0.0656 \\
\hline
\end{tabular}

Mean values having different superscripts along the same column are significantly different $(\mathrm{P} \geq 0.05)$.

Functional Properties of Black-eyed beans, Black beans and Brown beans flours.

The functional properties evaluated in the samples are water absorption capacity, oil absorption capacity, swelling index and bulk density.

Water absorption capacity (WAC) of the samples ranged from $2.52 \mathrm{~g} / \mathrm{g}$ for brown beans to $4.45 \mathrm{~g} / \mathrm{g}$ for blackeyed beans. The higher WAC value of the black-eyed beans could be attributed to its higher carbohydrate value. High water absorption capacity of the flour samples indicates the ability of the samples to absorb enough water during preparation of food samples such as baking and cooking of beans pudding. The water absorption capacity will in turn affect both the swelling index and the bulk density in direct proportions. Oil absorption capacity (OAC), of the samples were low, $3.24 \mathrm{~g} / \mathrm{g}$ for black-eyed beans, $3.55 \mathrm{~g} / \mathrm{g}$ for black beans and $3.54 \mathrm{~g} / \mathrm{g}$ for brown beans. The $\mathrm{OAC}$ values for the brown and black beans seed flour samples were not significantly different $(\mathrm{P} \geq 0.05)$. Oil absorption capacity of a food sample is of great importance since fats and oil act as flavor retainer and increases the mouth feel of food products (Aremu et al., 2007).

Bulk density of the legumes flour samples ranged from $0.43 \mathrm{~g} / \mathrm{cm}^{3}$ for brown beans to $0.64 \mathrm{~g} / \mathrm{cm}^{3}$ for blackeyed beans. The bulk density of black beans and black-eyed beans were not significantly different $(\mathrm{P} \leq 0.05)$. Bulk density gives an indication of the relative volume and type of packaging material requires. It is also affected by particle size of the flour. Flours with smaller particle sizes tend to have lower bulk densities. Particle sizes in turn are affected by the degree of milling. Low bulk densities as obtained in this work, ensures more food intake, thus more and better nutrition to the consumer. Swelling index of the samples ranged from $0.44 \mathrm{~g} / \mathrm{cm}^{3}$ for brown beans sample, $8.63 \mathrm{~g} / \mathrm{cm}^{3}$ for black beans sample to $10.63 \mathrm{~g} / \mathrm{cm}^{3}$ for black-eyed beans sample. The high value of some of the samples could be attributed to the starch content of the samples. Higher bulk index and water absorption capacity, make for higher swelling index.

Table 2: Functional Properties of Black-eyed beans, Black beans and Brown beans

\begin{tabular}{lcccc}
\hline Parameters/Samples & $\begin{array}{c}\text { Water Absorption } \\
\text { Capacity }(\mathbf{g} / \mathbf{g})\end{array}$ & $\begin{array}{c}\text { Oil Absorption } \\
\text { Capacity }(\mathbf{g} / \mathbf{g})\end{array}$ & $\begin{array}{c}\text { Bulk Density } \\
(\mathbf{g} / \mathbf{c m} 3)\end{array}$ & $\begin{array}{c}\text { Swelling Index } \\
(\mathbf{g} / \mathbf{c m} 3)\end{array}$ \\
\hline A Black eyed beans & $4.45^{\mathrm{a}} \pm 0.21$ & $3.24^{\mathrm{b}} \pm 0.02^{\mathrm{b}}$ & $0.64^{\mathrm{a}} \pm 0.03$ & $10.63^{\mathrm{a}} \pm 0.01$ \\
B Black beans & $3.44^{\mathrm{b}} \pm 0.02$ & $3.55^{\mathrm{a}} \pm 0.05$ & $0.63^{\mathrm{a}} \pm 0.01$ & $8.63^{\mathrm{b}} \pm 0.01$ \\
C Brown beans & $2.54^{\mathrm{c}} \pm 0.01$ & $3.54^{\mathrm{a}} \pm 0.04^{\mathrm{b}}$ & $0.43^{\mathrm{b}} \pm 0.02$ & $0.44^{\mathrm{c}} \pm 0.02$ \\
L.S.D & $\mathbf{0 . 0 9 8 7}$ & $\mathbf{0 . 0 3 3 2}$ & $\mathbf{0 . 0 1 6 8}$ & $\mathbf{0 . 0 1 0 1}$ \\
\hline
\end{tabular}

Mean values having different superscripts along the same column are significantly different $(\mathrm{P} \geq 0.05)$

\section{Anti-Nutritional Properties}

The anti-nutritional properties of black-eyed beans, black beans and brown beans evaluated were; saponin, trypsin inhibitor, Haemaglutin, alkaloid, phytate and tannin (Table 3). Deshelling of the beans aided in reducing their antinutrient contents. Saponin content of beans flours were $0.67 \mathrm{mg} / 100 \mathrm{~g}$ for black-eyed beans, $1.62 \mathrm{mg} / 100 \mathrm{~g}$ for black beans and $1.47 \mathrm{mg} / 100 \mathrm{~g}$ for brown beans. The low values of saponin obtained could be due to the processes employed during its production, which entailed deshelling and washing during which some of the anti-nutrients, including saponins would have leached into the water.

Trypsin inhibitors are mostly found in legumes thus making its elimination during processing necessary in order to reduce its toxicity level in the flours. Trypsin inhibitor content of beans flour samples were $1.54 \mathrm{mg} / 100 \mathrm{~g}$ for black-eyed beans, $1.62 \mathrm{mg} / 100 \mathrm{~g}$ for black beans and $1.75 \mathrm{mg} / 100 \mathrm{~g}$ for brown beans. Oven drying employed during processing also helped in the reduction of trypsin inhibitors (Iwe, 2002). The Haemaglutin content of the beans flour samples were $0.55 \mathrm{mg} / 100 \mathrm{~g}$ for black-eyed beans, $0.56 \mathrm{mg} / 100 \mathrm{~g}$ for brown beans and $0.64 \mathrm{mg} / 100 \mathrm{~g}$ for brown beans. Soybean has the highest level of Haemaglutin compared to black eyed beans, black beans and brown beans. The Alkaloid content of the samples was low, $0.27 \mathrm{mg} / 100 \mathrm{~g}$ for black-eyed beans, $0.34 \mathrm{mg} / 100 \mathrm{~g}$ for black beans and $0.22 \mathrm{mg} / 100 \mathrm{~g}$ for brown beans. Phytate content of the samples were $0.183 \mathrm{mg} / 100 \mathrm{~g}$ for black-eyed beans, $0.26 \mathrm{mg} / 100 \mathrm{~g}$ for black beans and $0.287 \mathrm{mg} / 100 \mathrm{~g}$ for brown beans. Tannins which are polyphenols and polyphenolic compounds are water soluble in nature. Tannins tend to reduce during wet processing due to leaching out of phenols into water (Uzogara et al., 1990). The tannin content was, $1.24 \mathrm{mg} / 100 \mathrm{~g}$ for black-eyed beans, 
$1.65 \mathrm{mg} / 100 \mathrm{~g}$ for black beans and $1.47 \mathrm{mg} / 100 \mathrm{~g}$ for brown beans. Soaking, deshelling and oven drying are very effective in reducing or eliminating soluble anti-nutritional factors; by discarding the soak water and giving attention to drying temperature and time.

Table 3: Anti-nutritional composition of Black-eyed beans, Black beans and Brown beans flours.

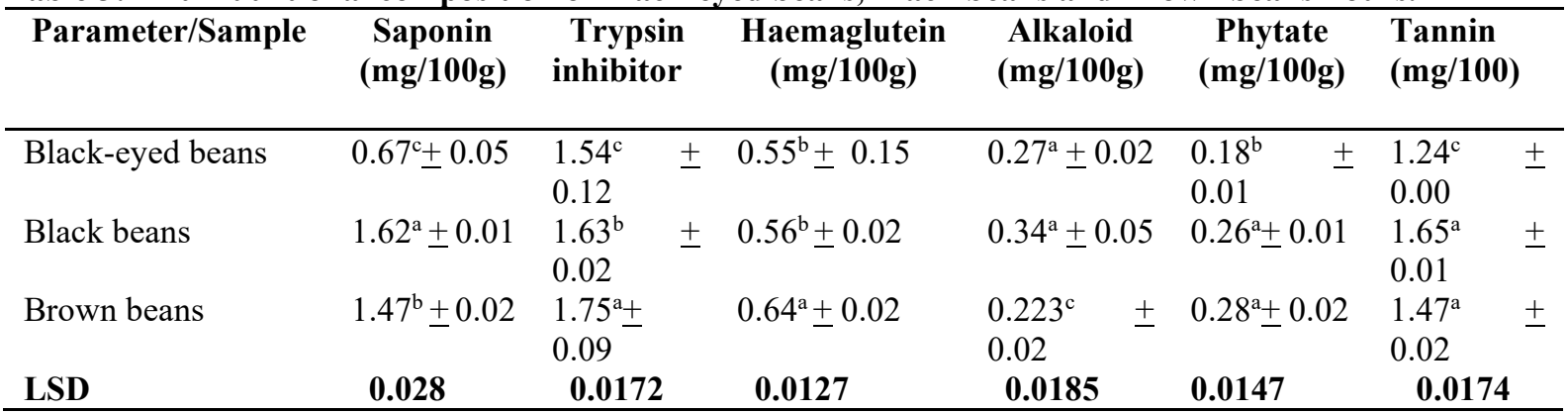

Mean values having different superscripts along the same column are significantly different $(\mathrm{P} \geq 0.05)$.

\section{0: Conclusion and Recommendation}

Black eyed beans, Black and Brown turtle beans are pulses of leguminosae family. The pulses studied are rich in food nutrients and some essential amino acids. They can be eaten whole or processed into intermediate products which could be further incorporated into other food products to create value additions, enrichments and value chain. The proximate analysis of the samples, Functional properties and anti- nutrients properties were examined. The black eyed beans contain more nutrients than the others. Further research should be done to determine the dough characteristics. The high nutrient contents should be noted and farmers encouraged increasing their propagation.

\section{References}

Abbey, B. \& Ibeh, G., 1998. Functional Properties of raw heat Processed cowpea flours. Journal of Food Science, 53 (6), pp. 17-18.

AOAC, 2006. Association of Official Analytical Chemist. Association of Official Analytical Chemist, 17th edition, pp. 214-245.

Aremu, M. O. O. A. E., 2007. Functional Properties of some Nigerian Varieties of Legumes, seed flours and flour concentrations:effect on foaming and gelation properties. Journal of Food Technology, 5(2), pp. 109 - 115.

Eka, A., 2016. Production and quality of canned moin-moin. Journal of Food Science, Volume 45, pp. 1359-1362.

Gami, S. B. D. E. N., 1992. Proximate and Functional Properties of Winged beans. Nigerian Journal of Nutrition Science, 42(10), pp. 182-185.

Harborne, C. O., 2000. Chemical Composition, physical and sensory properties of flours supplemented with white cassava and plantain flour. International Journal of Agricultural Policy and Research, 38(20), pp. 36 - 38.

Iwe, 2002. Handbook on sensory methods and analysis Communication Service. pp. 7 -12.

John, G. F. J. B. O. F., 2015. Chemical composition and nutritive changes of some improved varieties of cowpea (Vigna uniguiculata). International Institute for Tropical Agriculture, Ibadan Nigeria, TROPICAL sCIENCE, 28(10), pp. 191 - 199.

Odo, E. K., 2010. Properties of Trona and its effect on the cooking time of cowpeas. Journal of Food Science and Agriculture, 29(16), pp. 950 - 952.

Oyewole, Y. R., 2006. Effect of pre-decortications drying treatment on the microstructure of cowpea products. Journal of Food Science, 55(14), pp. 774 - 776.

Uzogara, S. A. I. U. E. N., 1990. A Review of Traditional Femented foods condiments and beverages in Nigeria: Benefits and possible problems. Econogy. Journal of Ecology of food and nutrition, 24(4), pp. 282 - 283.

Williams, S. R., 2007. dRY PEA(PISUM SATIVUM) canning quality as influenced by soak time, soak solution, and cultivar. Journal of Food Science, 50(18), pp. 238 -240. 